\title{
Difference Analysis of Digital Marketing Implementation in Enterprises Performance: Balanced Scorecard Perspective
}

\author{
Slamet $^{1 *}$, Muhammad Maslukil Adhim², Ilya Azmala ${ }^{3}$ \\ ${ }^{1,2}$ Universitas Islam Negeri Maulana Malik Ibrahim Malang, Jl. Gajayana 50 Malang, Jawa Timur \\ ${ }^{3}$ Universitas Brawijaya Malang, Jl. Veteran, Ketawanggede, Malang, Jawa Timur
}

\section{A R T I C L E I N F O

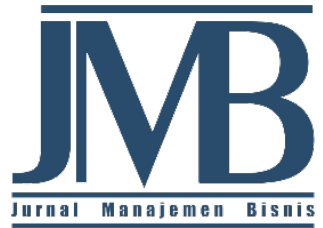

\begin{abstract}
Authors Email :
1slametphd@manajemen.uinmalang.ac.id

2maslukiladhim@gmail.com

3ilyaazmala7@gmail.com
\end{abstract}

Keywords:

Micro, Small and Medium Enterprises; Performance; Before and After; Digital Marketing; Balanced Scorecard

DOI:

https://doi.org/10.33096/jmb.v8i2.642

\begin{abstract}
A B S T R A C T
This study aims to determine the differences in Micro, Small, and Medium Enterprises' (MSMEs) performance before and after implementing digital marketing. The research paradigm was quantitative with primary data sources. Furthermore, the research instrument was a questionnaire designed to measure MSMEs' performance in the balanced scorecard perspective on customer and internal business processes. The number of samples totaled 107 respondents, and data were collected directly from MSMEs in Malang City. The determination of respondents involved a judgment sampling approach. Data analysis was mainly descriptive (categorization index) which also involved hypothesis testing (sample paired t-test). The results showed that there were significant differences in MSMEs' performance before and after implementing digital marketing. These differences were shown by the results of data analysis, in both descriptive and hypothesis testing.
\end{abstract}

\section{INTRODUCTION}

Micro, Small, and Medium Enterprises (MSMEs) play a strategic role in improving the economy (Kompasiana, 2019). This strategic role of MSMEs needs to be enhanced in terms of competitiveness. One of the factors for realizing competitiveness is the utilization of information technology (IT). The use of IT and the internet is a business transformation strategy, ensures the appropriate and efficient exchange of information, expansion of marketing networks, and market share, known as digital marketing. The term 'Digital marketing' describes the projections of conventional marketing, tools, and marketing strategies on the internet (Machado \& Davim, 2016). Furthermore, MSME actors have a great interest in the use of social media marketing (Purwana et al., 2017). About $14 \%$ of MSME actors have used online platforms in marketing their products (Kontan, 2020). In Central Java, 3.5\% of MSMEs use the internet as a medium for marketing their products (Surya, 2020). In Malang City, 38\% of MSMEs have used the internet (Biro Pusat Statistik, 2019), and other sources also state that $30 \%$ of the 70 thousand have gone online (Rumawati, 2017). Meanwhile, the Ministry 
of Communication and Information Technology stated that 6.4 million MSMEs were selling online in 2018 and is expected to increase in 2019 (Christiyaningsih, 2019). Although digital marketing is a new phenomenon in achieving marketing goals (Machado \& Davim, 2016), it has significantly influenced MSMEs' performance (Hendrawan et al., 2019).

Studies on performance measurement and digital marketing at MSMEs have been carried out by many researchers. A study by Kurniasari \& Memarista (2017) examined enterprise performance using the balanced scorecard method. Audira (2018) studied the role of digital marketing in the development of MSMEs. Pradiani (2018) conducted a study to test the implementation of digital marketing on MSME products. Similar to the study conducted by Pradiani (2018), Hendrawan et al. (2019) conducted digital marketing testing on the sales performance of MSMEs. Furthermore, Wahirayasa \& Kusuma (2018) and Lanang et al. (2014) examined the role of e-marketing on enterprise performance. Another study observed that MSMEs face problems, including capital (Anggraini \& Nasution, 2013), marketing factors, and human resources (Kiran et al., 2012). Therefore, there are several differences when compared to previous studies. The differences lie in the scope and objectives of each study. There has not been any previous study examining the differences in MSMEs performance before and after implementing digital marketing with measurement parameters using the Balanced Scorecard. A similar study was conducted by Hendrawan et al. (2019), but did not involve the Balance Scorecard and did not examine differences in performance before and after implementing digital marketing.

The study of performance measurement before and after implementation of digital marketing is essential. Because digital marketing involves technology and supporting infrastructure requires additional investment. Therefore, the implementation of digital marketing must know its impact on the MSMEs performance to motivate MSMEs the others. Digital marketing is defined as a projection of marketing tools and strategies on the Internet and is also called digital media. Digital media involves the use of all electronic media to process, decode, and transmit digital materials such as encoded audio, video, and photo content (Nuseir, 2018). The media has driven the development of channels, formats, and marketing languages to produce unthinkable tools and strategies in offline marketing (Machado \& Davim, 2016). Furthermore, digital marketing has become a new phenomenon unifying the marketing concept as a whole. The convergence of information technology and the internet has enhanced a new strategy for MSMEs in Indonesia. Digital marketing has also pushed the boundaries of conventional marketing, and MSMEs are no longer allergic to this new marketing concept. For example, MSME of bag craftsmen in Gulang Village has successfully implemented e-marketing packaged in a website application (Susanti, 2018). Several other MSMEs implemented digital marketing and obtained the benefits of directly interacting with consumers, expanding market share, and increasing sales (Febriyantoro \& Arisandi, 2018). Consequently, improving MSMEs performance certainly involves the concept of digital marketing in business management.

The advantages of digital marketing are: (1) user-centered, more scalable, ubiquitous, and interactive; (2) able to offer lots of potential for brands and companies; (3) able to brand products; (4) allows information dissemination via consumer links; (5) more functional and effective; (6) interactive; (7) able to communicate visually; (8) effective in conducting advertisements and promotions; (9) able to build virtual communities; and (10) sharing online platforms (Machado \& Davim, 2016). Through these advantages, it is expected that there will be significant differences in the performance of MSMEs before and after implementing digital 
marketing. This is based on the results of previous studies (Hendrawan et al., 2019; Chen et al., 2016; Wahirayasa \& Kusuma, 2018). Therefore, the utilization of digital marketing is suitable for MSME actors to improve their enterprise performance.

The enterprise performance is measured through several approaches, including using the Balanced Scorecard concept developed by Robert S. Kaplan (1996). This concept states that there are four comprehensive and interrelated measurement perspectives. However, this study used the perspective of customers and internal business processes as a method of measuring the MSMEs performance. The customer perspective is the view of external customers and the organization, which is an important factor for creating success in finance. This can be observed from two points of view, namely through measurement of the core customer and customer value proposition. The internal business process perspective is a process of creating value for customers. This involves a strategy map in explaining the steps to achieve enterprise goals. Many enterprises simultaneously create values in different ways. Therefore, an easy approach in measuring enterprise performance in this perspective is the value chain model (Hanuma, 2011). This model is a set of activities within an enterprise with an aim to create value for customers, which leads to competitive advantage and profitability creation (Porter, 1990). Accordingly, the concept of the Balanced Scorecard is effectively used to measure MSMEs performance.

This study aims to determine MSMEs' performance before and after implementing digital marketing. The background of this study is an argument that many MSMEs still have doubts about implementing digital marketing. This doubt is based on the MSME's lack of knowledge on the importance of the digital marketing concept and its impact on customers. The development of information technology supported by internet sophistication has massively influenced consumer behavior. Therefore, this study is expected to provide MSMEs confidence in implementing digital marketing.

\section{METHODS}

Based on the study objectives, a quantitative research design was applied. The scope of this study is the MSMEs in Malang City that have implemented digital marketing in their business management. The number of samples was determined using Maholtra's theory, namely at least four or five times the number of statements (Malhotra, 2014). In this study, there were 22 statements, while the samples totaled 88 respondents. However, the total number of valid samples was 107 respondents from 120 distributed instruments, as $10.83 \%$ were considered inappropriate. The sampling technique involved the Judgment Sampling approach. This means that in determining respondents, MSMEs that are used as subjects are the ones that have implemented digital marketing.

Data were obtained from primary sources, directly from MSME actors in Malang City that implemented digital marketing. These five sub-districts consist of Blimbing, Lowokwaru, Klojen, Kedungkandang, and Sukun Sub-district. The instrument in this study was a questionnaire developed based on the concept of a Balanced Scorecard with a customer perspective $\left(X_{.1}\right)$ and an internal business process perspective $\left(X_{.2}\right)$. Each perspective was used to measure the MSMEs performance before and after implementing digital marketing. Furthermore, measurement indicators for customer perspective $\left(X_{.1}\right)$, include business profit $\left(X_{-1.1}\right)$, achievement of targeted sales $\left(X_{1.2}\right)$, service quality $\left(X_{.1 .3}\right)$, product quality $\left(X_{.1 .4}\right)$, customer satisfaction(x.1.5), consumer loyalty $\left(X_{.1 .6}\right)$, good relationship with customers $\left(X_{.1 .7}\right)$, strategy effectiveness $\left(X_{.1 .8}\right)$, satisfying service $\left(X_{.1 .9}\right)$, promotional effectiveness $\left(X_{1.10}\right)$, 
advertising effectiveness $\left(X_{.111}\right)$, customer complaints $\left(X_{1.12}\right)$, a sense of security in shopping $\left(\mathrm{X}_{1.13}\right)$, and the level of profit $\left(\mathrm{X}_{1.14}\right)$. Meanwhile, indicators of the internal business process perspective $(X .2)$, include innovation $\left(X_{.2 .1}\right)$, product development $\left(X_{.2 .2}\right)$, product suitability $\left(\mathrm{X}_{2.3 .3}\right)$, business trend suitability $\left(\mathrm{X}_{.2 .4}\right)$, transaction models $\left(\mathrm{X}_{.2 .5}\right)$, production regularity $\left(\mathrm{X}_{2.6}\right)$, use of social media $\left(\mathrm{X}_{.2 .7}\right)$, and complaint resolution $\left(\mathrm{X}_{.2 .8}\right)$. The measurement used the Likert scale $(1$ = strongly disagree to 5 = strongly agree).

Data analysis involved two approaches, namely descriptive and hypothesis testing. Descriptive analysis used the index categorization method (Azwar, 2012) with three categories. First, the Low category $(X<$ Mean -1Std.Dev.); second, the Medium category (Mean - 1Std.Dev. $\leq X<$ Mean + 1Std.Dev.); and third, the High category (Mean + 1Std.Dev. $\leq X)$. Meanwhile, the analysis of hypothesis testing involved the Paired Sample t-Test method with an error rate $(\alpha)=5 \%$. The paired sample t-test is conducted on two paired samples. The decision criteria, Ho is accepted (no difference) if Sig. prob. $>0.05(5 \%)$, and Ho is rejected (there is a difference), if Sig.prob. $\leq 0.05(5 \%)$. The calculation of statistical formulas was performed using the SPSS application.

\section{RESULTS AND DISCUSSION}

\section{Results}

The study results are shown descriptively with the results of hypothesis testing. Table 1 shows the descriptive data analysis of the differences between before and after implementing digital marketing from customers' and internal business processes. Each perspective is divided into three categories, namely low, medium, and high groups.

Table 1: Description of Respondents' Answers

\begin{tabular}{llcc}
\hline \multirow{2}{*}{$\begin{array}{l}\text { Perspectives } \\
\text { Customer }\end{array}$} & Categorization & $\begin{array}{c}\text { Fefore } \\
\text { Implementing } \\
\text { Digital Marketing }\end{array}$ & $\begin{array}{c}\text { After Implementing } \\
\text { Digital Marketing }\end{array}$ \\
\hline & Low & $22,12 \%$ & $2,98 \%$ \\
& Medium & $68,09 \%$ & $20,56 \%$ \\
& High & $9,79 \%$ & $76,46 \%$ \\
\hline Internal Business Process & Total & $100 \%$ & $100 \%$ \\
& Low & 11,985 & $0,34 \%$ \\
& Medium & $73,57 \%$ & $9,79 \%$ \\
& High & $14,45 \%$ & $89,87 \%$ \\
\cline { 2 - 4 } & Total & $100 \%$ & $100 \%$ \\
\hline
\end{tabular}

Source: Primary Data (processed, 2020).

Table 1 showed that there were differences in respondents' answers based on the statement item indicators for each perspective before and after implementing digital marketing in MSME business management. Before implementing digital marketing, the customer perspective and internal business processes showed a trend in the medium category. Meanwhile, after implementing digital marketing, there was a trend to the high category. Therefore, before and after implementing digital marketing, the performance of MSME actors was different.

Before conducting the hypothesis testing, the data was first tested for its normality. The normality test technique uses the Kolmogorov-Smirnov because the sample groups are from 
the same population. This normality test aims to determine the distribution of data from digital marketing variables. Statistically, normality data illustrates that the respondents have similar perspectives in seeing the importance of digital marketing. The results of the analysis are shown in Table 2.2.

Table 2: Normality Test

\begin{tabular}{ccc}
\hline MSME Performance & Kolmogorov-Smirnov & Shapiro-Wilk \\
Before implementing digital marketing & 0,054 & 0.201 \\
After Implementing digital marketing & 0,200 & 0.117 \\
\hline
\end{tabular}

Source: Primary Data (processed, 2020)

The results of the data normality test using the Kolmogorov-Smirnov and ShapiroWilk methods showed that the data is normal. This is indicated by a value $>0.05(5 \%)$. Therefore, the data obtained from the population had a normal distribution or centered on the average. This means that the statement of one respondent is close to the same viewpoint as others.

Table 3 below shows the value of the descriptive analysis of each condition in the paired sample, and Table 4 shows the results of the different test. Based on Table 4 , it can be seen the Mean of the tested variables, Std. Deviation, Std. The Mena error, the t-statistical value of the paired test, the degrees of freedom from the test (d.f), and the p-value or significance of the test results $\{$ sig (2-tailed) $\}$. The information in this table is the basis for making hypothetical decisions.

Table 3: Paired Samples Statistics

\begin{tabular}{ccccc} 
& Mean & $\mathbf{N}$ & Std. Deviation & Std.Error Mean \\
Before & 73,09 & 107 & 5,094 & 0,589 \\
After & 97,83 & 107 & 5,628 & 0,544 \\
\hline
\end{tabular}

Source: Primary Data (processed, 2020)

Table 4: Hypothesis Test for Differences in MSMEs Performance

\begin{tabular}{|c|c|c|c|c|c|c|c|c|}
\hline & \multirow[t]{2}{*}{ Mean } & \multirow[t]{2}{*}{ Std.Dev. } & \multirow[t]{2}{*}{$\begin{array}{c}\text { Std.Error } \\
\text { Mean }\end{array}$} & \multicolumn{2}{|c|}{$\begin{array}{c}95 \% \text { Confidence } \\
\text { internal of the } \\
\text { difference }\end{array}$} & \multirow[t]{2}{*}{$\mathbf{t}$} & \multirow[t]{2}{*}{ df } & \multirow[t]{2}{*}{$\begin{array}{l}\text { Sig.(2- } \\
\text { tailed) }\end{array}$} \\
\hline & & & & Lower & Upper & & & \\
\hline Before-After & 24,738 & 8,349 & 0,807 & $-26,339$ & $-23,138$ & $-30,650$ & 106 & 0,000 \\
\hline
\end{tabular}

Source: Primary Data (processed, 2020)

Based on the hypothesis decision criteria, there is a statistically significant difference in MSMEs' performance before and after implementing digital marketing. This difference is indicated by the number Sig. $=0.00<0.05(5 \%)$. Consequently, both data analysis approaches, descriptive and hypothesis testing, produced the same indication of differences.

Discussion

Referring to the results of data analysis using the Balanced Scorecard approach with descriptive data analysis and hypothesis testing, there is a statistically significant difference. Descriptively, there is a difference in the MSMEs performance trend from before to after implementing digital marketing. Before implementing digital marketing, both the customer 
and the internal business process perspectives showed medium categories. However, after implementing digital marketing, MSME actors observed that their enterprise performance is in the high category. This descriptive analysis is strengthened by the results of the hypothesis test using the Paired sample t-test approach which indicated a difference. Therefore, the two analytical approaches showed the same results. It can be stated that implementing digital marketing at MSMEs is able to improve their enterprise performance.

This difference signifies that digital marketing improves the business performance of MSME actors. Alternatively, after implementing digital marketing, the MSMEs performance was significantly better than before. As stated by Febriyantoro \& Arisandi (2018), digital marketing is able to provide benefits in business management, including the way business actors directly interact with customers, expand their market reach, and increase their sales. Machado \& Davim (2016) also have a similar opinion, that digital marketing provides many benefits, especially for MSME actors. Therefore, this study supports the results of a study conducted by Pradiani (2018), which stated that the role of digital marketing is to enhance MSME sales in the home industry sector. The same results were observed by Hendrawan et al. (2019) and Munizu (2010), that there is a significant positive effect of digital marketing on the sales performance of MSME products. Digital marketing is seen as a relevant medium applied by MSME actors. Furthermore, it can be used as an effective and efficient promotional tool. Compared to the old business model before implementing digital marketing, it also increases sales volume. Accordingly, to improve the MSMEs performance, it should be developed comprehensively (Respatiningsih, 2019; Ardiana \& Brahmayanti, 2010).

There were differences in the MSMEs performance before and after implementing digital marketing. This is because digital marketing was able to enhance business models. With digital marketing, enterprises develop more effective business models for their customers. Business management can also be made through websites, social media, content and email marketing, marketing automation, inbound and affiliate marketing (Digital, 2020). Another study showed that $88 \%$ more MSMEs utilize social media, 54\% used email marketing, 56\% used websites, $32 \%$ used video-based marketing, and 76\% of MSMEs believe that digital marketing is effective in achieving business goals (Peck, 2020). Therefore, digital marketing is truly capable of changing business models and enterprise performance, especially for MSME actors. Digital marketing can no longer be abandoned and should be utilized by MSME actors in Indonesia.

Although many previous studies examined digital marketing in MSMEs, this study is different. This study has proven that the concept of the Balanced Scorecard can still be used to measure the MSMEs performance with digital marketing as the driver. Meanwhile, other studies do not involve aspects of MSME performance, digital marketing, and Balanced Scorecard comprehensively. A study by Kurniasari \& Memarista (2017) only measured enterprise performance using the Balanced Scorecard method but did not involve digital marketing as the driver. Likewise, Audira (2018) and Pradiani (2018) only examined the role of digital marketing in MSMEs, but did not involve the Balanced Scorecard as a measurement method. The same study by Hendrawan et al. (2019), conducted digital marketing testing on the sales performance of MSMEs. This study was limited to examining the effect of digital marketing as an independent variable on MSME sales as the dependent variable. Consequently, this strengthens the previous study but differs in methods.

To improve the MSMEs performance in the Malang area, the local government - the Service Office of Cooperatives and Micro Enterprises of Malang - must massively mobilize digital-based MSMEs through training and increase knowledge about the importance of 
digital marketing in the digital era. Considering that MSMEs have a large number of economic actors, they have to be appreciated as having made a significant contribution to the growth of the Indonesian economy. Furthermore, the involvement of information technology and the internet is expected to increase the competitiveness of MSME actors. The strategies that can be developed include website development for MSME actors, using social media, or joining an available online platform (marketplace). This is the responsibility of the government and digital marketing activists. In addition, the results of this study provide important information for local governments and SMEs that digital marketing is important in improving the performance of SMEs in the digital era.

\section{CONCLUSION}

The most important result in this study is the effect of digital marketing on MSMEs performance. The Balanced Scorecard is also a feasible method to measure the performance of business management. Digital marketing is no longer seen as a challenge, but is an opportunity for MSME actors in Indonesia. The implementation of digital marketing has been proven to increase MSMEs' performance. Furthermore, digital marketing is no longer a luxury and expensive item, but has become an absolute necessity for all MSME actors in Indonesia to take advantage of. It has developed rapidly and massively along with changes in Indonesian consumer thinking and behavior. Most consumers in Indonesia are already dependent on information technology and internet networks. This shows that digital marketing is an opportunity to improve business management. Meanwhile, for academics which have an interest in measuring enterprise performance, the concept of the Balanced Scorecard is appropriate for use as a comprehensive performance measurement method. The four perspectives in the Balanced Scorecard are related to one another. Consequently, digital marketing should be utilized by MSME actors. To specifically measure their performance, the Balanced Scorecard method can be applied.

However, this study still has limitations or deficiencies. This is observed in the use of the Balanced Scorecard method. This study only highlighted two perspectives, namely the customer perspective and internal business processes. In the Balanced Scorecard, there were four perspectives, namely financial, customers, internal business processes, as well as learning and growth perspectives. The limitations lie in research methods, namely the quantitative research paradigm with the nature of a closed questionnaire. Therefore, it is recommended that further researchers refine this study and strengthen their methods. The four perspectives can be developed simultaneously using the mixed method. This will enable future studies to be more perfect and provide more accurate knowledge and information.

\section{REFERENCES}

Anggraini, D., \& Nasution, S. (2013). Peranan Kredit Usaha Rakyat (KUR) bagi pengembangan umkm di Kota Medan (studi kasus bank BRI). Jurnal Ekonomi Dan Keuangan, 1(3), 105116. Retrieved from https://www.neliti.com/publications/14879/peranan-kreditusaha-rakyat-kur-bagi-pengembangan-umkm-di-kota-medan-studi-kasus

Ardiana, I. D. K. R., \& Brahmayanti, I. A. (2010). Kompetensi SDM UKM dan Pengaruhnya Terhadap Kinerja UKM di Surabaya. Jurnal Manajemen Dan Kewirausahaan, 12(1), 42-55. https://doi.org/10.9744/jmk.12.1.pp.42-55

Audira, N. (2018). Analisis Peranan Pelatihan Program Kampung Ukm Digital Terhadap Perkembangan Umkm Dalam Perspektif Ekonomi Islam (Studi Pada KUB Telo Rezeki Sentra Industri Keripik Kota Bandar Lampung). Universitas Islam Negeri Raden Intan Lampung. 
Azwar, S. (2012). Penyusunan Skala Psikologi (2nd ed.). Pustaka Pelajar.

Biro Pusat Statistik. (2019). Profil Industri Mikro Dan Kecil Kota Malang Tahun 2019. Retrieved from

https:// malangkota.bps.go.id/publication/download.html?nrbvfeve=YmRiYTRkZDhh N2FINGEwYmQ4YjA3Zjc2\&xzmn=aHR0cHM6Ly9tYWxhbmdrb3RhLmJwcy5nby5pZC 9wdWJsaWNhdGlvbi8yMDIxLzA1LzA3L2JkYmE0ZGQ4YTdhZTRhMGJkOGIwN2Y3 Ni9wcm9maWwtaW5kdXN0cmktbWlrcm8tZGFuLWtlY2lsLWtvdGEtb

Chen, Y. Y. K., Jaw, Y. L., \& Wu, B. L. (2016). Effect of digital transformation on organisational performance of SMEs: Evidence from the Taiwanese textile industry's web portal. Internet Research, 26(1), 1-42. https:/ / doi.org/10.1108/IntR-12-2013-0265

Christiyaningsih. (2019, June 19). Delapan Juta UMKM Ditargetkan Melek Internet Pada 2019. Republika. Retrieved from https:/ / nasional.republika.co.id/berita/nasional/umum/ptcen2459/delapan-jutaumkm-ditargetkan-melek-internet-pada-2019

Digital, D. (2020). Apa Pengertian Digital Marketing dan Manfaatnya untuk Bisnis ? DHA Digital Indonesia. Retrieved from https://www.dhadigital.com/apa-itu-digitalmarketing/\#: :text=Tujuan utama dari “digital marketing,untuk kepentingan usaha atau bisnis.

Febriyantoro, M. T., \& Arisandi, D. (2018). Pemanfaatan Digital Marketing Bagi Usaha Mikro, Kecil Dan Menengah Pada Era Masyarakat Ekonomi Asean. JMD: Jurnal Riset Manajemen $\mathcal{E}$ Bisnis Dewantara, 1(2), 62-76. https://doi.org/10.26533/jmd.v1i2.175

Hanuma, S. (2011). Analisis balance scorecard sebagai alat pengukuran kinerja perusahaan (Studi Kasus pada PT. Astra Honda Motor). In Thesis. Universitas Diponegoro.

Hendrawan, A., Sucahyowati, H., Cahyandi, K., Indriyani, \& Rayendra, A. (2019). Pengaruh Marketing Digital Terhadap Kinerja Penjualan Produk UMKM Asti Gauri di Kecamatan Bantasari Cilacap. Jurnal Administrasi Dan Kesekretarisan, 4(1), 53-60. Retrieved from http://www.jurnal.stiks-tarakanita.ac.id/index.php/JAK/article/view/189/136

Kiran, P. V., Majumdar Dr. Mousumi, \& Kishore, P. K. (2012). Innovative marketing strategies for micro, small \& medium enterprises. Interdisciplinary Journal of Contemporary Research in Business, Volume 4(2), 1059-1066. Retrieved from https://journalarchieves19.webs.com/1059-1066.pdf

Kompasiana. (2019, October 11). Teknologi Informasi dalam Usaha Kecil Menengah. Kompas. Retrieved from https://www.kompasiana.com/arhanx/5d9f8dcd0d82307ecd50d4f2/teknologiinformasi-dalam-usaha-kecil-menengah

Kontan. (2020, October 7). Program Digitalisasi UMKM Rakyat Indonesia. Kontan. Retrieved from https:// pressrelease.kontan.co.id/release/program-digitalisasi-umkm-rakyatindonesia

Kurniasari, V., \& Memarista, G. (2017). Analisis Kinerja Perusahaan Menggunakan Metode Balanced Scorecard ( Studi Kasus Pada PT. Aditya Sentana Agro ). Agora, 5(1). Retrieved from https://media.neliti.com/media/publications/55327-ID-analisis-kinerjaperusahaan-menggunakan.pdf

Lanang, I. P. E. S., Kirya, I. K., \& Cipta, I. W. (2014). Analisis Faktor-Faktor Yang Mempengaruhi Kinerja Usaha Mikro Kecil Dan Menengah (UMKM) Di Kabupaten Bangli. E-Journal Bisma Universitas Pendidikan Ganesha, 2(1), 11-21.

Machado, C., \& Davim, J. P. (2016). Theory and application of Business and managemente Principles. Springer. $\quad$ Retrieved from https://www.researchgate.net/publication/312190728_Understanding_Digital_Market ing-Basics_and_Actions

Malhotra, N. (2014). Fundamentals of Marketing Research. In Fundamentals of Marketing Research. https://doi.org/10.4135/9781446261767

Munizu, M. (2010). Pengaruh Faktor-Faktor Eksternal dan Internal Terhadap Kinerja Usaha 
Mikro dan Kecil (UMK) di Sulawesi Selatan. Jurnal Manajemen Dan Kewirausahaan, 12(1), 33-41. https:// doi.org/10.9744/jmk.12.1.pp.33-41

Nuseir, M. T. (2018). Digital media impact on smes performance in the UAE. Academy of Entrepreneurship Journal, 24(2), 1-13. Retrieved from https:// www.abacademies.org/articles/Digital-Media-Impact-on-SMEs-Performancein-the-UAE-1528-2686-24-2-134.pdf

Peck, A. (2020). 7 Digital Marketing Tips for Small Businesses. The Manifest. Retrieved from https:/ / themanifest.com/ digital-marketing/small-business-digital-marketing-tips-2020

Porter, M. (1990). Competitive Advantage of Nations. Competitive Intelligence Review. https:// doi.org/10.1002/cir.3880010112

Pradiani, T. (2018). Pengaruh Sistem Pemasaran Digital Marketing Terhadap Peningkatan Volume Penjualan Hasil Industri Rumahan. Jurnal Ilmiah Bisnis Dan Ekonomi Asia, 11(2), 46-53. https://doi.org/10.32812/jibeka.v11i2.45

Purwana, D., Rahmi, R., \& Aditya, S. (2017). Pemanfaatan Digital Marketing Bagi Usaha Mikro, Kecil, Dan Menengah (UMKM) Di Kelurahan Malaka Sari, Duren Sawit. Jurnal Pemberdayaan Masyarakat Madani (JPMM), 1(1), 1-17. Retrieved from https:/ / doi.org/10.21009/jpmm.001.1.01

Respatiningsih, H. (2019). Manajemen Kinerja Usaha Mikro Kecil Dan Menengah (UMKM). Jurnal Manajemen Dan Bisnis, 15(2), 48-65. Retrieved from http://ejournal.umpwr.ac.id/index.php/segmen/article/view/5746

Robert S. Kaplan, D. N. (1996). The Balance ScoreCard. Harvard Business School Press.

Rumawati, S. (2017). Menuju go online, ini 5 tantangan utama UMKM kota Malang. Retrieved from Merdeka.com. https://m.merdeka.com/malang/gaya-hidup/menuju-go-onlineini-5-tantangan-utama-umkm-kota-malang-171106x.html

Surya, M. (2020, April 11). Baru 3,5 persen UMKM di Jateng memanfaatkan internet. AntaraNews. Retrieved from https://www.antaranews.com/berita/1411426/baru-35persen-umkm-di-jateng-manfaatkan-internet

Susanti, N. (2018). Perancangan e-marketing UMKM kerajinan Tas. Simetris: Jurnal Teknik Mesin, Elektro Dan Ilmu Komputer, 9(1), 717-722. Retrieved from https:// doi.org/10.24176/simet.v9i1.2042

Wahirayasa, C. G., \& Kusuma, A. A. G. A. A. (2018). Peran E-Marketing Dalam Memediasi Pengaruh Orientasi Pasar Terhadap Kinerja Bisnis. E-Jurnal Manajemen Universitas Udayana, 7(6), 3291-3391. Retrieved from https:// doi.org/10.24843/EJMUNUD.2018.v07.i06.p16 